\title{
Pengembangan Program Sistem Informasi Akuntansi Berbasis Akrual Sesuai dengan Standar Akuntansi Pemerintahan (SAP)
}

\author{
Yudhi Kurniawan \\ Program Studi Sistem Informasi \\ Fakultas Sains Dan Teknologi, Universitas Ma Chung \\ Villa Puncak Tidar N-01, Malang, Jawa Timur \\ yudhi.kurniawan@machung.ac.id
}

\author{
Yuswanto \\ Program Studi Akuntansi \\ Fakultas Ekonomi Dan Bisnis, Universitas Ma Chung \\ Villa Puncak Tidar N-01, Malang, Jawa Timur \\ yuswanto@machung.ac.id
}

Abstrak-Penelitian ini mengkaji cara praktis mendesain pelaporan Akuntansi Keuangan Daerah yang berbasis Akrual yang sesuai dengan standar Akuntansi Pemerintahan. Tujuan penelitian tersebut adalah membuat perangkat lunak Sistem Informasi Akuntansi dengan menggunakan metode pelaporan akuntansi yang berbasis Akrual yang disesuaikan dengan Standar Akuntansi Pemerintahan. Harapan yang ingin dicapai adalah perangkat lunak yang digunakan di Sektor Pemerintahan dapat mendukung kinerja dan hasil pelaporan keuangan yang relevan.

Data yang digunakan berasal dari kajian tentang Standar Akuntansi Pemerintahan dan pelaporan Keuangan Daerah berbasis Akrual yang dibuat dalam bentuk dokumen analisa dan kebutuhan sistem. Hasil capaian di tahun pertama telah selesai dikerjakan yaitu terselesaikannya dokumentasi analisa kebutuhan perangkat lunak dan spesifikasi desain proses sertadata dan antarmuka program.

Diharapkan dengan penelitian ini dapat mengimplementasikan sistem, modularitas program dari dokumentasi analisa kebutuhan dan desain perangkat lunak serta instalasi program pada Sistem Informasi Akuntansi berbasis Akrual. Pada akhir penelitian diharapkan dapat diperoleh suatu perangkat lunak dalam bentuk Sistem Informasi Keuangan Daerah yang sesuai dengan Standar Akuntansi Pemerintahan serta berbasis akrual. Kedepannya bentuk perangkat lunak tersebut dapat menjadi pionir bagi pelaporan keuangan sesuai yang dibutuhkan.

Kata-katakunci: Akuntansi Keuangan Daerah, Sistem Informasi Akuntansi, berbasis akrual, Standar Akuntansi Pemerintahan

\section{Pendahuluan}

Peraturan Pemerintah (PP) Nomor 71 Tahun 2010 tentang Standar Akuntansi Pemerintahan, pasal 4 ayat (1) menegaskan bahwa Pemerintah menerapkan Standar Akuntansi Pemerintahan (SAP) berbasis akrual. SAP berbasis akrual merupakan standar akuntansi yang mengakui pendapatan, beban, aset, utang, dan ekuitas dalam pelaporan finansial berbasis akrual, serta mengakui pendapatan, belanja, dan pembiayaan dalam pelaporan pelaksanaan anggaran berdasarkan basis yang ditetapkan dalam APBN/APBD. Oleh karena itu Pemerintah Daerah wajib menyusun laporan keuangan yang terdiri Laporan Pelaksanaan Anggaran dan Laporan Finansial. Pelaksanaan Anggaran meliputiLaporan Realisasi Anggaran (LRA) dan Laporan Perubahan SAL, sementara itu Laporan financial terdiri dariNeraca, Laporan Operasional (LO), Laporan Perubahan Ekuitas serta Laporan Arus Kas. Disamping itu SKPD harus menyusun Catatan atas Laporan Keuangan (CaLK) (Margono, 2015).

Satuan Kerja Perangkat Daerah harus menyusun LRA yaitu laporan yang menyajikan informasi mengenai pendapatan dan belanja baik anggaran maupun relaisasinya yang pengakuannya menggunakan dasar pengakuan sesuai dokumen anggaran. Selain itu Satuan Kerja Perangkat Daerah juga diwajibkan membuat LO yaitu laporan yang menyajikan pendapatan dan beban yang pengakuannya berdasarkan dasar akrual. Adanya dua laporan tersebut menimbulkan persoalan teknis dalam pencatatannya, yaitu bagaimana membuat cataatan akuntansi yang menjadi dasar dalam dalam penyusunan laporan keuangan pelaksanaan anggaran dan laporan finansial.

Permasalahan yang timbul adalah masih banyak Satuan Kerja Perangkat Daerah yang belum menerapkan SAP. Bahkan setelah dikeluarkan PP Nomor 71 Tahun 2010 tentang SAP sebagai pengganti dari PP Nomor 24 Tahun 2015, penerapan basis akrual pada akuntansi pemerintahan belum bisa dilaksanakan. Hal ini dikarenakan adanya kendala yang dihadapi dalam penerapan SAP (Yafie, 2013).

Dari hasil kajian tentang penerpan akuntansi berbasis akrual diperoleh bahwa umumnya bentuk pelaporannya menerapkan dual system, yaitu sistem akuntansi berbasis akrual dan penganggaran barbasis kas. Penerapan seperti ini dikenal dengan nama akuntansi berbasis kas menuju basis akrual (Simanjuntak, 2010). Perubahan seperti ini merupakan reformasi di bidang keuangan negara dan harus dilakukan secara bertahap seperti yang diamanatkan dalam UndangUndang No. 17 Tahun 2013.

Kesulitan dalam menerapkan akuntansi berbasis akrual tersebut perlu didimbangi dengan pemakaian teknologi informasi dalam pembuatan pelaporannya. Keberadaan 
teknologi informasi dapat dengan mudah mengubah lingkungan akuntansi khususnya dari sisi kecepatan dan keakuratan dalam perhitungan data-data akuntansi.

Sebuah lembaga di Amerika yang bernama American Institute of Certified Public (AICPA) telah membuat sertifikat baru dengan nama Certified Information Technology Profesional (CITP), mendokumentasikan keahlian sistem para akuntan yaitu akuntan yang memiliki pengetahuan luas di bidang teknologi dan yang memahami bagaimana teknologi informasi dapat digunakan dalam berbagai bidang organisasi. Hal ini mencerminkan pengakuan AICPA atas pentingnya teknologi informasi dan hubungannya dengan akuntansi (Handayani, 2007)

Seiring dengan kebutuhan Sistem Informasi Akuntansi pada penerapan aktivitas dan kegiatan akuntansi berbasis akrual dibutuhkan teknologi informasi guna mempermudah proses pencatatan akuntansinya. Pencatatan hingga pelaporan akuntansi berbasis akrual tersebut bertujuan untuk menghasilkan pelaporan keuangan yang relevan dan bermanfaat dalam menilai kinerja pemerintah daerah.

Manfaat pelaporan keuangan berbasis akrual bertujuan agar pengguna dapat mengidentifikasi posisi keuangan pemerintah dan perubahannya. Dari informasi tersebut diharapkan bahwa pemerintah dapat mendanai kegiatan yang sesuai dengan kemampuan pendanaannya sehingga dapat diukur kapasitas pemerintah yang sebenarnya. Selain itu manfaat dari penerapan dari teknologi informasi dalam bentuk pengembangan sistem informasi akuntansi berbasis akrual yang sesuai dengan Standar Akuntansi Pemerintahan dapat dijaga kerahasiaan dan kebenaran data, keutuhan dan integritas data dengan lebih maksimal. Hal ini dikarenakan perangkat lunak yang dihasilkan dapat dimanfaatkan oleh berbagai pihak yang berwenang.

Fokus dari penelitian ini adalah mendesain Software Requirement untuk Sistem Informasi Akuntansi Keuangan Daerah yang mematuhi Standard 830-1998 tentang Software Requirement Specification dari IEEE (Institute of Electrical and Electronics Engineers) (IEEE, 1998). Detail proses yang digunakan adalah Software Requirement Process, Requirement Elictitation dan Problem Domain, Business Requirement Analysis serta detail dalam Software Requirement Specification.

\section{TINJAUAN PUSTAKA}

\section{A. Akuntansi Berbasis Akrual}

Akuntansi berbasis akrual adalah suatu basis akuntansi di mana transaksi ekonomi dan peristiwa lainnya diakui dan disajikan dalam laporan keuangan pada saat terjadinya transaksi tersebut, tanpa memperhatikan waktu kas atau setara kas diterima atau dibayarkan (KSAP, 2006). Dengan demikian, pendapatan diakui pada saat penghasilan telah diperoleh dan biaya diakui pada saat kewajiban timbul atau sumber daya dikonsumsi. Penerapan basis akrual mencakup pencatatan transaksi keuangan dan juga penyiapan laporan keuangan (Widjajarso, 2010).

Menurut Simanjuntak (2010) akuntansi berbasis akrual adalah suatu basis akuntansi di mana transaksi ekonomi dan peristiwa lainnya diakui, dicatat, dan disajikan dalam laporan keuangan pada saat terjadinya transaksi tersebut, tanpa memperhatikan waktu kas atau setara kas diterima atau dibayarkan. Dalam akuntansi berbasis akrual, waktu pencatatan sesuai dengan saat terjadinya arus sumber daya, sehingga dapat menyediakan informasi yang paling komprehensif karena seluruh arus sumber daya dicatat.

\section{B. Standar Akuntansi Pemerintahan}

Standar Akuntansi Pemerintahan (SAP) dikeluarkan melalui Peraturan Pemerintah Nomor 24 Tahun 2005 yang merupakan tonggak dasar bahwa Indonesia telah memiliki standar baku untuk akuntansi pemerintahan. SAP tersebut berbasis kas sehingga pengakuan transaksi pendapatan, belanja, dan pembiayaan berbasis akrual untuk pengakuan aset, kewajiban, dan ekuitas dana.

Penyempurnaan dari Peraturan Pemerintah Nomor 24 Tahun 2005 tentang Standar Akuntansi Pemerintahan adalah dengan diterbitkannya Peraturan Pemerintah Nomor 71 Tahun 2010.Standar Akuntansi Pemerintahan dinyatakan dalam bentuk Pernyataan Standar Akuntansi Pemerintahan (PSAP), dilengkapi dengan Pengantar Standar Akuntansi Pemerintahan dan disusun berdasarkan Kerangka Konseptual Akuntansi Pemerintahan. Keberadaan SAP harus digunakan dalam menyusun laporan keuangan pemerintah, baik Pemerintah Pusat maupun Pemerintah Daerah.

C. Perencanaan, Perancangan dan Pengembangan Sistem Informasi

Menurut Kendall (2005), Analisa dan Perancangan Sistem digunakan untuk menganalisis, merancang, dan mengimplementasikan peningkatan-peningkatan fungsi bisnis yang dapat dicapai melalui penggunaan sistem informasi terkomputerisasi. Komponen dasar yang harus tersedia adalah desain input, desain output, desain database, dan desain antarmuka. Tindak lanjut dari analisis dan perancangan sistem adalah terbentuknya sistem informasi Whitten (2004).

Banyak organisasi menganggap sistem informasi diperlukan untuk memiliki kemampuan bersaing atau memperoleh keuntungan persaingan. Dalam tahap ini sistem akan dikembangkan dengan model web base serta disesuaikan dengan framework yang dibuat sendiri tanpa menggunakan framework yang sudah ada dan tetap dengan dukungan CSS, Javascript dan HTML 5. Hal ini bertujuan untuk memberikan kemudahan user dalam mengakases sistem, secara umum framework yang digunakan mengacu pada Model-ViewController (MVC).

MVC merupakan sebuah konsep yang diperkenalkan oleh penemu Smalltalk (Trygve Reenskaug) untuk meng- 
enkapsulasi data bersama dengan pemrosesan (model), mengisolasi dari proses manipulasi (controller) dan tampilan (view) untuk dipresentasikan pada sebuah user interface (Deacon, 2009). MVC mengikuti pendekatan yang paling umum dari Layering yaitu sebuah logika yang membagi kode ke dalam fungsi di kelas yang berbeda. Pendekatan ini mudah dikenal dan paling banyak diterima. Keuntungan utama dalam pendekaktan ini adalah penggunaan ulang (reusability) kode (Satish, 2004).

Menurut Burbeck (1992) definisi teknis dan arsitektur MVC dibagi menjadi tiga lapisan, yaitu:

a. Model, digunakan untuk mengelola informasi dan memberitahu pengamat ketika ada perubahan informasi. Hanya model yang mengandung data dan fungsi yang berhubungan dengan pemrosesan data.

b. View, bertanggungjawab untuk pemetaan grafis ke sebuah perangkat dan biasanya memiliki hubungan one to onedengan sebuah permukaan layar dan tahu bagaimana untuk membuatnya. View melekat pada model dan merender isinya ke permukaan layar.

c. Controller, menerima input dari pengguna dan menginstruksikan model dan view untuk melakukan aksi berdasarkan masukan tersebut. Controller bertanggungjawab untuk pemetaan aksi pengguna akhir terhadap respon aplikasi.

Menurut Hidayat (2012) Model, view, dan controller sangat erat terkait sehingga ketiga lapisan tersebut harus merujuk satu sama lainnya. Arsitektur seperti ini memiliki beberapa manfaat yaitu pemisahan antara model dan view memungkinkan beberapa view menggunakan model yang sama.

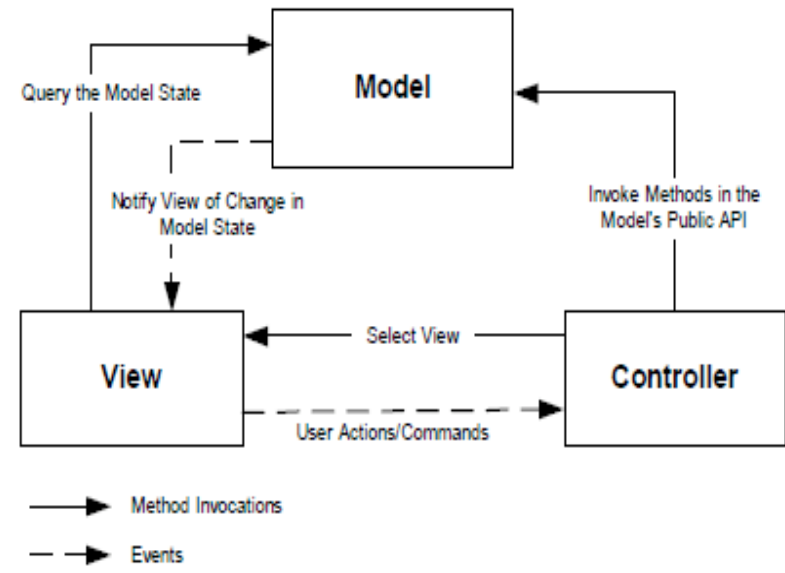

Gambar 1. Hubungan antara model, view, dan controller (Gulzar, 2002)

\section{METODOLOGI PENELITIAN}

Penelitian ini adalah penelitian pengembangan sistem informasi yaitu melakukan implementasi metodologi pada studi kasus nyata di lapangan, dengn tujuan untuk menghasilkan sebuah sistem lengkap dengan sub sistem dan fungsi yang sesuai dalam Sistem Informasi Akuntansi di Pemerintahan. Metodologi pengembangan sistem ini menggunakan Agile Development Methods dengan tujuan menghasilkan kualitas dari perangkat lunak yang bagus dan seimbang antara kebutuhan pengguna dengan pengembangan sistem(Kaushal Pathak dan Anju Saha, 2013).

1. Perencanaan Sistem

Pada langkah ini pengembang dan klien membuat rencana tentang kebutuhan dari yang akan dibuat, dalam rencana kebutuhan melibatkan beberapa aktivitas dalam tahapan requirement yang dimulai pada tahapan Requirement Engineering Process, Requirement Elicitation, Requirement Analysis, dan menghasilkan Software Requirement Specifications.

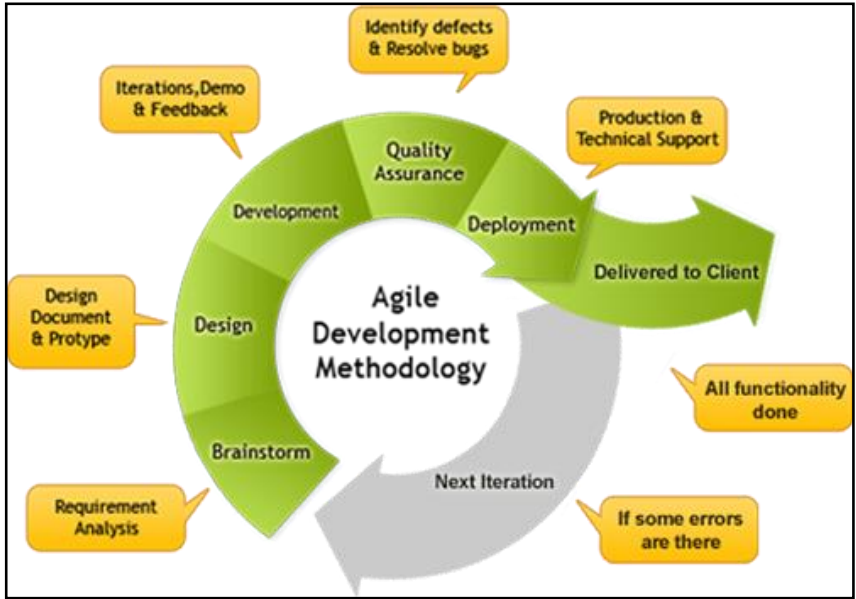

Gambar 2 : Kerangka Kerja Pengembangan Sistem

\section{Implementasi (Design \& Development)}

Bagian dari proses ini dimana prorgrammer melakukan pengkodean perangkat lunak dalam bentuk desain dan coding aplikasi, dalam desain dimulai dengan define software design basic concepts, software architecture, software desaign quality analysis and evaluation, software design notations, dan menghasilkan software design description. Setelah tahapan desain selesai dilakukan, tahapan selanjutanya dalam fase yang sama memasuki software contruction dengan pilihan Method Linguistic Construction Methods, Formal Contruction Methods And Visual Construction Methods.

3. Tes Perangkat Lunak (Identify defects \& Resolve bugs)

Perangkat lunak yang telah dibuat di tes oleh bagian control kualitas agar bug yang ditemukan bisa segera 
diperbaiki rules dalam testing dipilih menggunakan black box testing concepts dalam Basic Concepts And Definitions, dengan memperhatikan Test Levels dan Test Techniques dan diakhiri dengan melakukan Test Related Measures

4. Dokumentasi

Setelah dilakukan tes perangkat lunak langkah selanjutnya yaitu proses dokumentasi perangkat lunak untuk mempermudah tahapan maintenance, kedepannya dokumentasi dihasilkan dari reverse engineering sesuai dengan aplikasi yang sudah dibuat.

\section{Deployment (Production \& Technical Support)}

Proses yang dilakukan oleh penjamin kualitas untuk menguji kualitas sistem sudah dilaksanakan sesuai prosedur dan setelah sistem memenuhi syarat maka perangkat lunak siap di deployment and delivery to client dengan mempersiapkan Techincal Support dalam bentuk helpdesk atau supporting system.

6. Maintenance

Langkah terakhir dari fase pengembangan sistem yaitu pemeliharaan, pemeliharan ini adalah pemeliharaan rutin yang terdiri dari backup dan restore yang bersifat operasional bukan penambahan fungsi akibat perubahan bisnis proses pada organisasi yang menjalankan. Detail kegiatan dalam tahapan ini adalah Maintenance Activities, Maintenance Process, Organizational Aspects Of Maintenance, Problems Of Software Maintenance, Maintenance Cost, Maintenance Measurement And Techniques for Maintenance.

\section{HASIL DAN PEMBAHASAN}

Proses pembuatan Software Requirement Specification (SRS) untuk Sistem Informasi Akuntansi berbasis akrual dibagi menjadi 3 tahapan, yaitu:

A. Requirement Elictitation

Sistem Informasi Akuntansi Daerah mempunyai beberapa sub sistem yang membentuk sistem itu sendiri secara utuh dengan integrasi basis data untuk keseluruhan, sub sistem yang dimaksud adalah :

1. Sub Sistem Anggaran

2. Sub Sistem Penatausahaan

3. Sub Sistem Pembukuan/Akuntansi

4. Sub Sistem Master Data Modul

Arah/domain dari sistem yang dikembangkan berfungsi untuk melakukan aktivitas pengelolaan keuangan daerah sesuai dengan siklus dan Standar Akuntansi Pemerintahan yang berbasis akrual.

Tabel 1. Daftar Fungsi dan Sub Sistem

\begin{tabular}{|l|l|}
\hline \multicolumn{1}{|c|}{ Sub Sistem } & \multicolumn{1}{c|}{ Deskripsi/Fungsi } \\
\hline Sub Sistem Anggaran & Sub Sistem yang digunakan untuk \\
& melakukan kegiatan yang terkait \\
& dengan penyusunan Anggaran \\
& (APBD) sesuai dengan Program Dan \\
& Kegiatan yang sudah direncakan \\
\hline
\end{tabular}

\begin{tabular}{|l|l|}
\hline \multicolumn{1}{|c|}{ Sub Sistem } & \multicolumn{1}{c|}{ Deskripsi/Fungsi } \\
\hline Sub Sistem Penatausahaan & $\begin{array}{l}\text { Sub Sistem yang digunakan untuk } \\
\text { melakukan penatausahaan terkait } \\
\text { dengan Penerimaan Pendapatan, } \\
\text { Pengeluaran, Dan Realisasi } \\
\text { Anggaran serta proyeksi dan } \\
\text { rencana pendapatan oleh pemerintah } \\
\text { daerah dalam satu tahun anggaran. }\end{array}$ \\
\hline $\begin{array}{l}\text { Sub Sistem } \\
\text { Pembukuan/Akuntansi }\end{array}$ & $\begin{array}{l}\text { Sub Sistem yang digunakan untuk } \\
\text { melakukan pembukuan/akuntansi } \\
\text { dari aktivitas yang sudah dilakukan } \\
\text { guna menghasilkan laporan } \\
\text { keuangan daerah yang berbasis } \\
\text { akrual dalam pelaksanaannnya }\end{array}$ \\
\hline $\begin{array}{l}\text { Sub Sistem Master Data } \\
\text { Modul }\end{array}$ & $\begin{array}{l}\text { Subtem yang digunakan untuk } \\
\text { mengatur master data dan } \\
\text { konfigurasi sistem serta keamanan } \\
\text { dari penggunaan sistem oleh selurh } \\
\text { stakeholder yang berwenang } \\
\text { menggunakan. }\end{array}$ \\
\hline
\end{tabular}

Business Function yang ada pada BUD selaku pemegang kendali aktivitas pengelolaan keuangan dipetakan menjadi 3 Functional Areasseperti pada gambar 3.

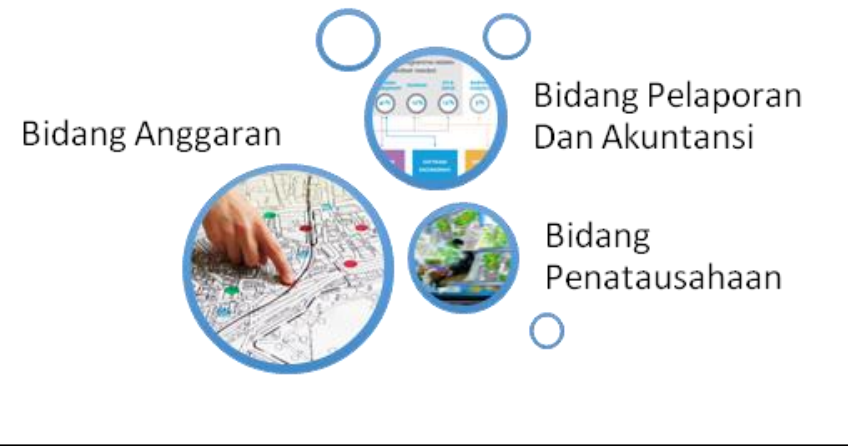

Gambar 3. Functional Areas Pengelola Keuangan Daerah

Tabel 2. Pemetaan Antara Business Process dan Business Function Pengelolaan Keuangan Daerah

\begin{tabular}{|c|c|c|c|}
\hline Input & $\begin{array}{c}\text { Functional } \\
\text { Area } \\
\text { Responsible } \\
\text { for input }\end{array}$ & Process & Output \\
\hline $\begin{array}{l}\text { Isian Dan } \\
\text { Detail } \\
\text { Kegiatan } \\
\text { Anggaran } \\
\text { dalam satu } \\
\text { semester }\end{array}$ & $\begin{array}{l}\text { Bidang } \\
\text { Anggaran }\end{array}$ & $\begin{array}{l}\text { Master Data } \\
\text { Fungsi Dan } \\
\text { urusan } \\
\text { pemerintahan } \\
\text { Master Satuan } \\
\text { Unit Kerja } \\
\text { Isian dan } \\
\text { Detail } \\
\text { Kegiatan }\end{array}$ & $\begin{array}{l}\text { RKA } \\
\text { SKPD/Kabup } \\
\text { aten } \\
\text { DPA } \\
\text { SKPD/Kabup } \\
\text { aten } \\
\text { DPPA } \\
\text { SKPD/Kabup } \\
\text { aten }\end{array}$ \\
\hline $\begin{array}{l}\text { Surat } \\
\text { Permohonan }\end{array}$ & $\begin{array}{l}\text { Bidang } \\
\text { Penatausahaan }\end{array}$ & $\begin{array}{l}\text { Data Isian Dan } \\
\text { Detail }\end{array}$ & SPP \\
\hline
\end{tabular}




\begin{tabular}{|c|c|c|c|}
\hline Input & $\begin{array}{l}\text { Functional } \\
\text { Area } \\
\text { Responsible } \\
\text { for input } \\
\end{array}$ & Process & Output \\
\hline Pembayaran & & $\begin{array}{l}\text { Kegiatan } \\
\text { Master Data } \\
\text { Bendahara } \\
\text { Dan Rekanan }\end{array}$ & \\
\hline $\begin{array}{l}\text { Surat } \\
\text { Perintah } \\
\text { Pembayaran }\end{array}$ & $\begin{array}{l}\text { Bidang } \\
\text { Penatausahaan }\end{array}$ & $\begin{array}{l}\text { Verifikasi Dan } \\
\text { Validasi Data } \\
\text { SPP }\end{array}$ & SPM \\
\hline $\begin{array}{l}\text { Surat } \\
\text { Perintah } \\
\text { Penyediaan } \\
\text { Dana (SP2D) }\end{array}$ & $\begin{array}{l}\text { Bidang } \\
\text { Penatausahaan } \\
\text { Bagian } \\
\text { Verifikasi }\end{array}$ & $\begin{array}{l}\text { Verifikasi Dan } \\
\text { Validasi Data } \\
\text { SPM }\end{array}$ & $\begin{array}{l}\text { Dokumen } \\
\text { SP2D }\end{array}$ \\
\hline $\begin{array}{l}\text { SKP/SKR } \\
\text { dan } \\
\text { Penyesuaian } \\
\text { SKP/SKR }\end{array}$ & $\begin{array}{l}\text { Bidang } \\
\text { Pembukuan/Ak } \\
\text { untansi }\end{array}$ & SKP/SKR & SKP/SKR \\
\hline $\begin{array}{l}\text { Jurnal } \\
\text { Penerimaan } \\
\text { dan } \\
\text { Pengeluaran } \\
\text { KS }\end{array}$ & $\begin{array}{l}\text { Bidang } \\
\text { Pembukuan/Ak } \\
\text { untansi }\end{array}$ & $\begin{array}{l}\text { Pembukuan } \\
\text { Aktivitas } \\
\text { Penerimaan } \\
\text { Kas Dan } \\
\text { Pengeluaran } \\
\text { Kas baik untuk } \\
\text { LS, UP, GU } \\
\text { atau TU }\end{array}$ & $\begin{array}{l}\text { Buku } \\
\text { Penerimaan } \\
\text { Kas } \\
\text { Buku } \\
\text { Pengeluaran } \\
\text { Kas } \\
\text { Buku Kas } \\
\text { Buku Besar } \\
\end{array}$ \\
\hline $\begin{array}{l}\text { Jurnal } \\
\text { Pengeluaran } \\
\text { PFK }\end{array}$ & $\begin{array}{l}\text { Bidang } \\
\text { Akuntansi/Pem } \\
\text { bukuan }\end{array}$ & $\begin{array}{l}\text { Pembukuan } \\
\text { Aktivitas } \\
\text { khusus untuk } \\
\text { transaksi PFK }\end{array}$ & Jurnal PFK \\
\hline Jurnal Umum & $\begin{array}{l}\text { Bidang } \\
\text { Akuntansi/Pem } \\
\text { bukuan }\end{array}$ & $\begin{array}{l}\text { Pembukuan } \\
\text { Jurnal Umum }\end{array}$ & Jurnal Umum \\
\hline $\begin{array}{l}\text { Jurnal LPE, } \\
\text { SAL, LO }\end{array}$ & $\begin{array}{l}\text { Bidang } \\
\text { Akuntansi } \\
\text { Pembukuan }\end{array}$ & $\begin{array}{l}\text { Aktivitas input } \\
\text { jurnal khusus }\end{array}$ & $\begin{array}{l}\text { Neraca Saldo, } \\
\text { Neraca Akhir, } \\
\text { Laporan LO, } \\
\text { Laporan LPE, } \\
\text { Dan Laporan } \\
\text { SAL }\end{array}$ \\
\hline
\end{tabular}

B. Requirement Analysis

Dari stakeholder yang ada maka sistem ini akan di gunakan oleh Pengelola Keuangan Daerah yang ditunjuk atau biasa disebut dengan Badan Pengelolaan Keuangan Dan Aset Daerah yang nantinya akan membawahi dari seluruh SKPD yang ada di lingkungan Pemerintah Daerah.Masing-masing SKPD akan menggunakan satu portal khusus sebagai link kedalam sistem dan mendapatkan hak akses sesuai dengan rules yang sudah didefinisikan oleh super administrator atau administrator.

C. Software Requirement Specifications

1) Deskripsi Sistem

Sistem Informasi Akuntansi ini adalah sistem yang digunakan oleh Badan Pengelolaan Keuangan Dan Aset Daerah pada Bidang Anggaran Dan Penatausahaan Keuangan terkait dengan Pengelolaan
Keuangan Daerah yang berbasis Akrual sesuai dengan Prinsip-prinsip pada Standar Akuntansi Pemerintah (SAP).

2) Asumsi dan Batasan Sistem

- Sistem ini digunakan oleh seluruh SKPD dilingkungan pemerintah daerah sebagai operator dan Badan Pengelola Keuangan dan Aset Daerah sebagai BUD atau satuan yang ditunjuk langsung oleh Bupati/Kepala Pemerintah Daerah sebagai penanggung jawab dalam pengelolaan keuangan daerah sesuai dengan prinsip-prinsip pengelolaan yang diatur oleh Peraturan Menteri Keuangan Dan Peraturan Kepala Daerah.

- Sistem ini hanya digunakan dalam pengelolaan keuangan daerah berbasis akrual dan menghasilkan laporan keuangan yang harus disediakan sesuai dengan ketetapan dalam pelaporan keuangan dalam setiap akhir tahun anggaran.

3) Fungsi dan Fitur Sistem

- Sistem ini digunakan untuk pengelolaan keuangan daerah sesuai dengan siklus pengelolaan keuangan daerah

- Sistem ini digunakan untuk bidang anggaran sebagai media dalam melakukan perancanaan anggaran, pembuatan RKA, pembuatan DPA, dan Pembuatan DPPA

- Sistem ini digunakan untuk bidang penatausahaan sebagai media dalam melakukan monitoring dan pelaksanaan dari RKA/DPPA dalam aktivitas pembuatan SPP, Pembuatan SPM, Verifikasi dan Validasi SPM dalam SP2D, Penerimaan Kas, Pengeluaran Kas, PFK.

- Sistem ini digunakan untuk bidang akuntansi/pembukuan sebagai media dalam melakukan kegiatan pengakuntansian yang meliputi aktivitas jurnal umul, jurnal LPE, jurnal LO, jurnal SAL untuk menghasilkan Laporan Neraca Akhir, Neraca Saldo, Laporan LO. Laporan SAL dan Laporan LPE.

4) Karakteristik Pengguna

Untuk entitas/pengguna dalam sistem tersebut dapat dikategorikan, yaitu Administrator, dan Operator, Pempinan/Pengambil Keputusan.

5) Kebutuhan Fungsional

Kebutuhan fungsional yang ada dalam Sistem ini terbagi menjadi 4 sub sistem, sebagai berikut.

1. Kebutuhan Fungsional User dan Sistem Sub Sistem Master Data Management

2. Kebutuhan Fungsional User dan Sistem Sub Sistem Anggaran

3. Kebutuhan Fungsional User dan Sistem Sub Sistem Penatausahaan 
4. Kebutuhan Fungsional User dan Sistem Sub Sistem Pembukuan/Akuntansi

5. Kebutuhan Fungsional User dan Sistem Sub Sistem Konfigurasi dan Keamanan Sistem

6) Kebutuhan Non Fungsional

Secara non fungsional kebutuhan daripada sistem dapat didefinisikan dengan beberapa parameter, yaitu Availability, Reliability, Ergonomy, Portability, Memory, ResponseTime, Safety, danSecurity.

7) Actor Identification

Dari karakterisitik pengguna yang sudah didefinisikan maka struktur pengguna secara model adalah sebagai berikut.

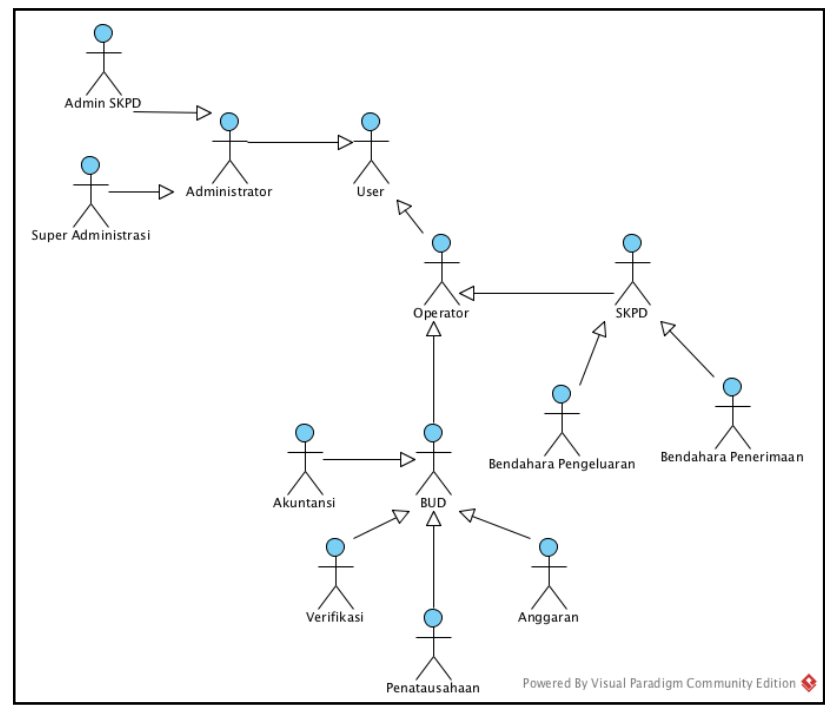

Gambar 4.Actor Structure

8) Use case Diagram

Dari masing-maisng pengguna mempunyai case yang dimodelkan dalam use case diagram

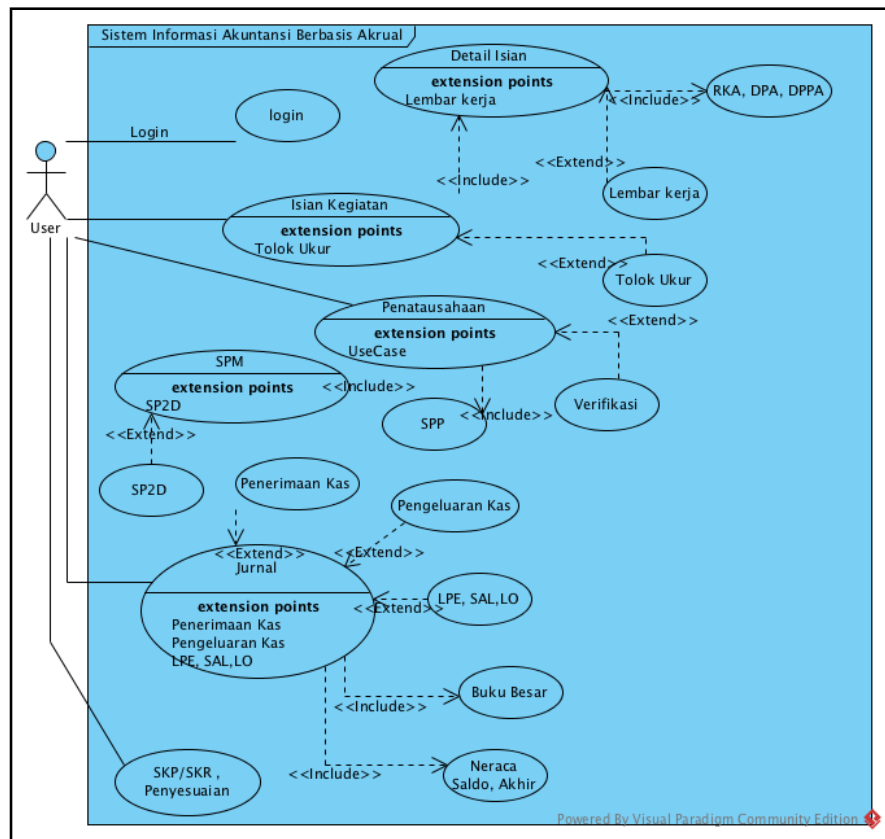

Gambar 5. Use Case Diagram Sistem Informasi Akuntansi Berbasis Akrual

9) UI/UX Sistem

Model dan tipe form yang digunakan meliputi type column, tabular dan grid sesuai dengan fungsi dari masing-masing form

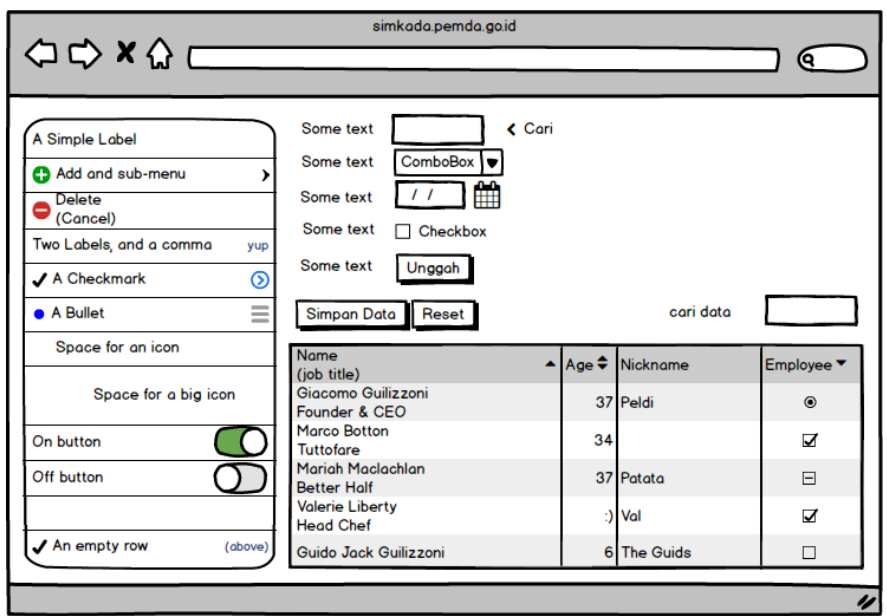

Gambar 6. Contoh Form dengan Tipe Tabular

Hasil implementasi dari blue print berupa program Program Sistem Informasi Akuntansi Berbasis Akrual Sesuai dengan Standar Akuntansi Pemerintahan (SAP)yang terdiri dari program master dan transaksi. Gambaran lengkap dari program tersebut, sebagai berikut.

1. Master Data Manajemen

Dalam master Organisasi/Urusan digunakan untuk menentukan dan mengelolah data terkait urusan oleh masing-masing SKPD. Fungsi dari masing-masing SKPD bidang kerja dan SKPD itu sendiri serta sekaligus Program Serta Kegiatan yang dimiliki oleh SKPD

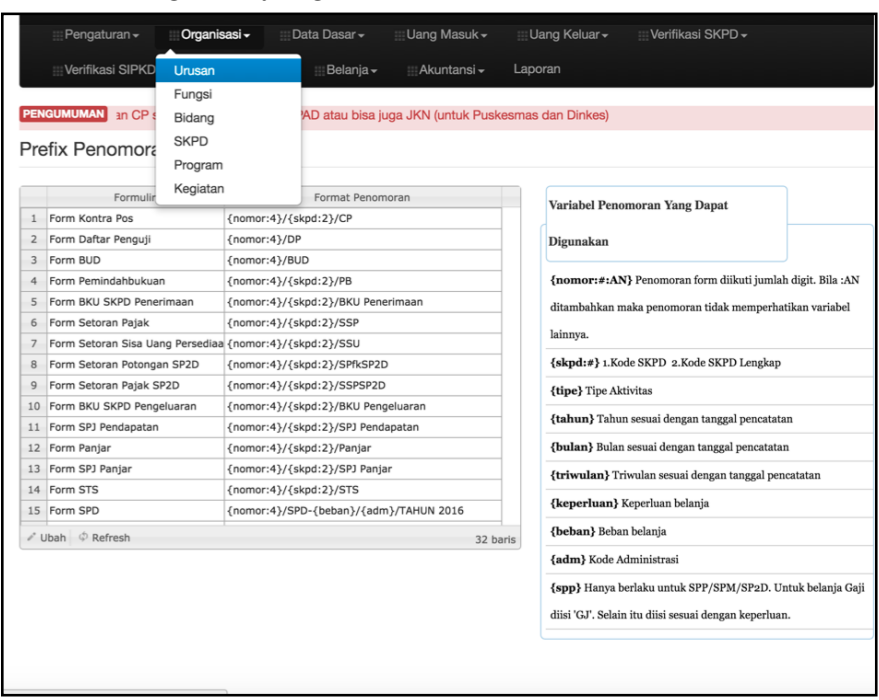


ISSN 2087-2658

Jurnal Nasional Pendidikan Teknik Informatika (JANAPATI)

Volume 5, Nomor 1, Maret 2016

Gambar 7. Tahapan desain Master Data Manajemen 2. Master Data Dasar

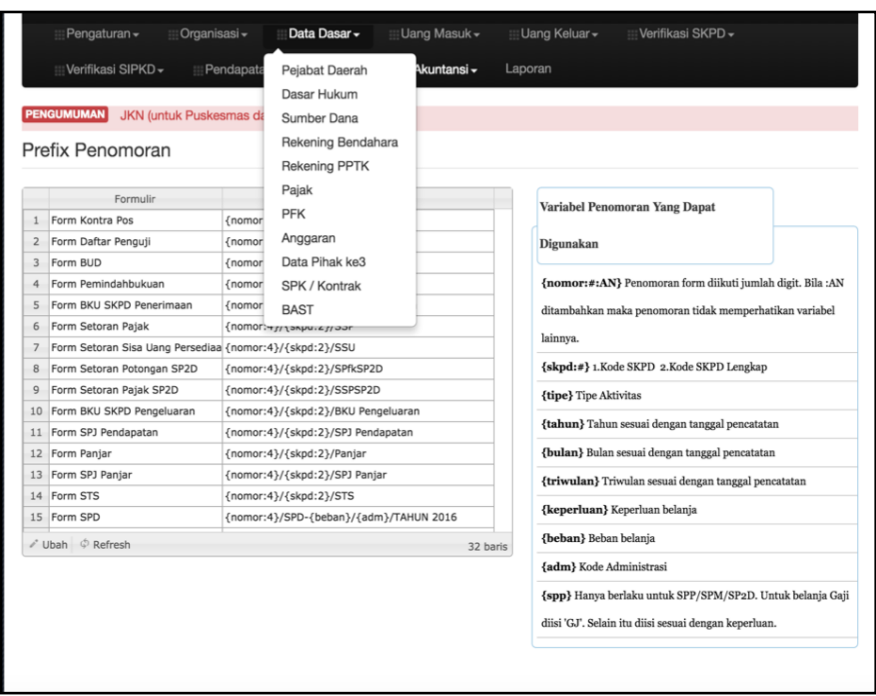

Gambar 8. Desain Sistem Master Data Dasar

Master data dasar merupakan menu dasar yang digunakan dalam sistem, sebagai berikut.

Tabel 3. Tabel fungsi Master Data Dasar

\begin{tabular}{|l|l|}
\hline \multicolumn{1}{|c|}{ Menu } & \multicolumn{1}{c|}{ Fungsinya } \\
\hline Daerah & $\begin{array}{l}\text { Untuk manajemen data pejabat } \\
\text { daerah yang akan tampil pada } \\
\text { laporan yang dihasilkan dari sistem }\end{array}$ \\
\hline $\begin{array}{l}\text { Master Dasar } \\
\text { Hukum }\end{array}$ & $\begin{array}{l}\text { Untuk manajemen data dasar hukum } \\
\text { dari keputusan ataupun aturan } \\
\text { terakit dengan pengelolaan } \\
\text { keuangan daerah }\end{array}$ \\
\hline Master sumber dana & $\begin{array}{l}\text { Untuk manajemen data sumber dana } \\
\text { yang dipakai sebagai parameter } \\
\text { pilihan utama ketika transaksi } \\
\text { dijalankan }\end{array}$ \\
\hline $\begin{array}{l}\text { Master Rekening } \\
\text { Bendahara }\end{array}$ & $\begin{array}{l}\text { Untuk manajemen data rekening } \\
\text { dari masing- masing bendahara pada } \\
\text { SKPD di lingkungan pemerintah } \\
\text { daerah }\end{array}$ \\
\hline $\begin{array}{l}\text { Master Rekening } \\
\text { PPTK }\end{array}$ & $\begin{array}{l}\text { Untuk manajemen data rekening } \\
\text { dari masing- masing PPTK pada } \\
\text { SKPD di lingkungan pemerintah } \\
\text { daerah }\end{array}$ \\
\hline Master Data Pihak & $\begin{array}{l}\text { Untuk manajemen data master pajak } \\
\text { dan jenis pajak yang dipungut atau } \\
\text { didapatkan }\end{array}$ \\
\hline Master Pajak & $\begin{array}{l}\text { Untuk menentukan dan manajemen } \\
\text { data anggaran /kode rekening yang } \\
\text { berlaku pada kegiatan Pengelolaan } \\
\text { Keuangan Daerah }\end{array}$ \\
\hline Master Anggaran
\end{tabular}

\begin{tabular}{|l|l|}
\hline \multicolumn{1}{|c|}{ Menu } & \multicolumn{1}{c|}{ Fungsinya } \\
\hline & $\begin{array}{l}\text { pengelolaan keuangan daerah } \\
\text { terutama pembayaran pekerjaan }\end{array}$ \\
\hline $\begin{array}{l}\text { Master } \\
\text { Kontrak/SPK }\end{array}$ & $\begin{array}{l}\text { Untuk mendaftar dan manajemen } \\
\text { data kontrak/spk dari kegiatan } \\
\text { pengadaan barang dan jasa yang } \\
\text { berjalan pada satu tahun anggaran }\end{array}$ \\
\hline Master BAST & $\begin{array}{l}\text { Untuk bridging sistem dengan } \\
\text { aplikasi aset/manajemen aset barang } \\
\text { daerah }\end{array}$ \\
\hline
\end{tabular}

\section{Transaksi Surat Penyediaan Dana}

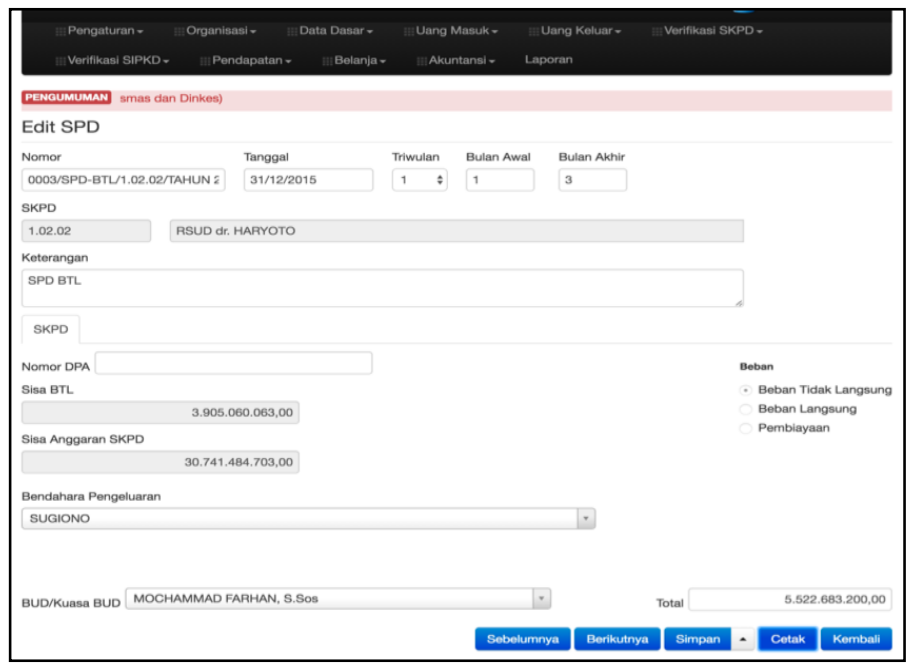

Gambar 9. Form Edit Surat Penyedia Dana

Transaksi ini digunakan untuk membuat Surat Penyediaan Dana atas suatu pekerjaan/kegiatan yang sudah dan akan dilaksanakan.

4. Transaksi Surat Permintaan Pembayaran

Transaksi Surat Permintaan Pembayaran merupakan transaksi lanjutan dari Surat Penyedia Dana yang sudah disetujui. Surat Permintaan Pembayaran yang dilakukan terhadap pihak ketiga yang sudah dibuat oleh masingmasing SKPD/ Bidang sesuai dengan fungsi dan urusan masing-masing SKPD ketika proses penganggaran dilaksanakan.

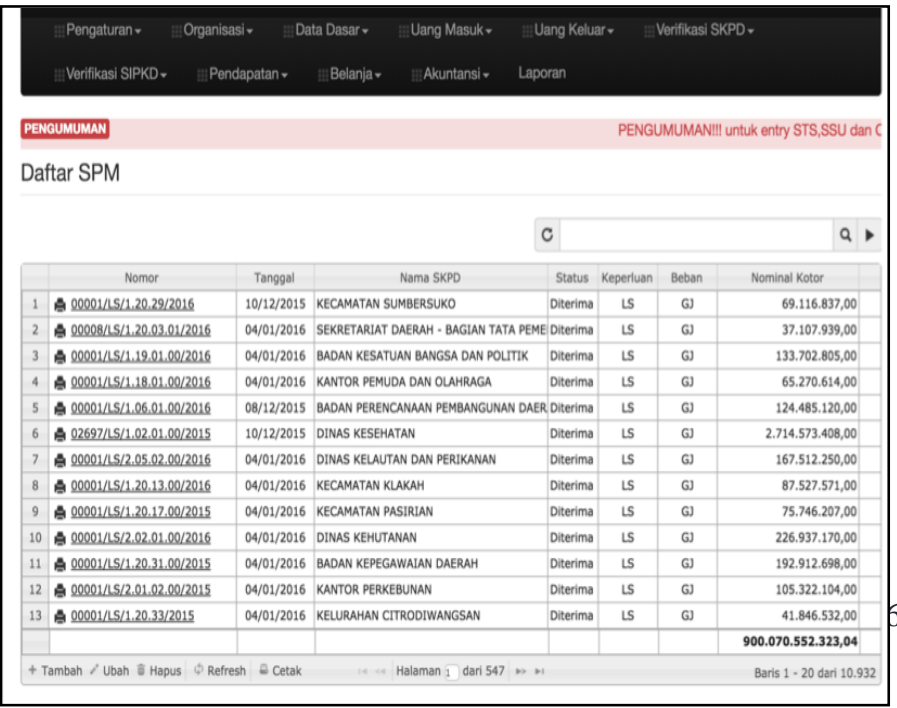


Gambar 10. Form Surat Permintaan Pembayaran

\section{Surat Perintah Membayar}

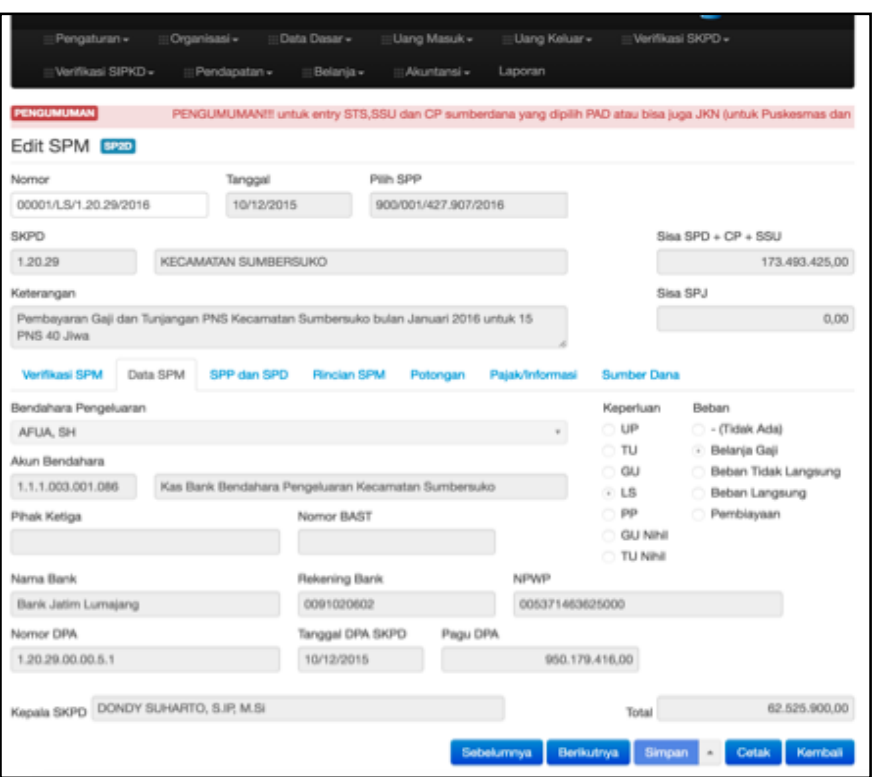

Gambar 11. Form Surat Perintah Membayar

Transaksi Surat Perintah Membayar digunakan untuk meneruskan sesuai alur siklus pengelolaan keuangan setelah adanya dokumen ataupun form Surat Permintaan Pembayaran yang dilanjutkan pada Surat Permintaan Pembayaran atas Surat Permintaan Pembayaran yang sudah diterbitkan dan direlease.

6. Surat Perintah Pencairan Dana

Transaksi Surat Perintah Pencairan Dana (SP2D) adalah dokumen yang digunakan sebagai dasar pencairan dana yang diterbitkan oleh Kuasa BUD berdasarkan Surat Perintah Membayar. Detail dari formulir SP2D adalah sebagai berikut.

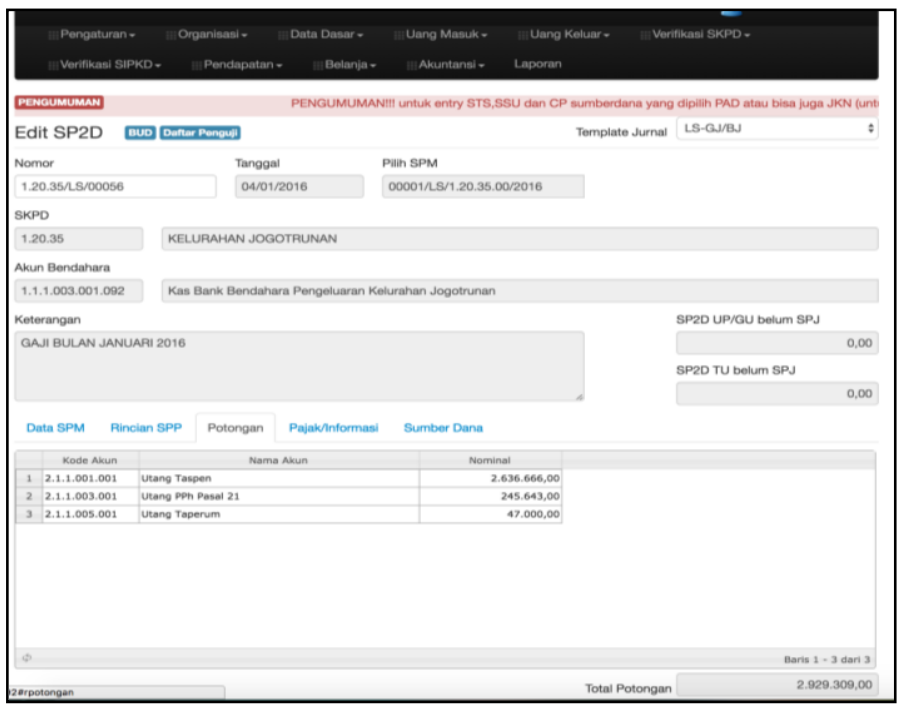

Gambar 12. Form Surat Perintah Pencairan Dana

\section{v. SIMPULAN DAN SARAN}

A. Simpulan

Spesifikasi Kebutuhan Perangkat Lunak untuk pengembangan Sistem Informasi Akuntansi berbasis Akrual sudah sesuai dengan proses bisnis dan fungsi yang diharapkan oleh pengguna, baik itu fungsi, batasan sistem dan detail kebutuhan fungsional dan non fungsional yang sudah di uji dan disampaikan kepada sample pengguna.

Software Requirement untuk Sistem Informasi Akuntansi Keuangan Daerah yang sesuai dengan Standard 830-1998 tentang Sosftware Requirements Specification dari IEEE. Implementasi program Sistem Informasi Akuntansi berbasis akrual sesuai dengan standar Akuntansi Pemerintahan.

B. Saran

1. Melakukan generate code dari model dan rancangan yang sudah dibuat secara otomatis untuk mempercepat proses pengkodean pada fase implementasi selanjutnya

2. Pada desain yang berbasis objek harus lebih di sempurnakan dengan melengkapi beberapa diagram alternatif sebagai model lain dari modeling primary yang sudah dibuat

\section{DAFTAR PUSTAKA}

Burbeck, Steven. 1992. Application Programmings in Smaltalk's 80 тм. How To Use MVC,(Online), (http://stwww.cs.illinois.edu/users/smarch/stdocs/mvc.ht ml, diakses tanggal 10 Maret 2014).

Deacon, John. 2009. Model-View-Controller Architecture, (Online) (http://www.jdl.co.uk/ briefings/index.html/\#mvc, diakses tanggal 10 Maret 2014)

Gulzar, Nadir. 2002. Fast track to struts: what it does and how,

(Online), (http://media.techtarget.com/tss/static/articles/content/Str utsFastTrack/StrutsFastTrack.pdf, diakses tanggal 11 Maret 2014)

Handayani, R. 2007. "Analisis Faktor-faktor yang Mempengaruhi Minat Pemanfaatan Sistem Informasi dan Penggunaan Sistem Informasi” (http://puslit.petra.ac.id/journals/accounting, diakses tanggal 11 Agustus 2015)

Hidayat, A. dan Surarso, B. 2012. Penerapan Arsitektur Model, View, dan Controller (MVC) dalam Rancang Bangun Sistem Kuis Online Adaptif. Seminar Nasional 
Teknologi Informasi dan Komunikasi 2012 (SENTIKA 2012)

IEEE, 830-1998.IEEE Recommended Practice For Software Requirements Specifications, California

IEEE, 2004. Software Engineering Body Of Knowledge (SWEBOK), Computer Society, California

Kaushal Pathak dan Anju Saha. 2013. "Review of Agile Software Development Methodologies," International Journal of Advanced Research in Computer Science and Software Engineering. Volume 3. February 2013

Kendal, K dan Kendall, J. 2005. Systems Analysis and Design $6^{\text {th }}$ Edition. Pearson International Edition. Prentice Hall

Komite Standar Akuntansi Pemerintahan (KSAP). 2005. Peraturan Pemerintah Nomor 24 tahun 2005 tentang Standar Akuntansi Pemerintahan. Jakarta: KSAP

Komite Standar Akuntansi Pemerintahan. 2006. Memorandum Pembahasan Penerapan Basis Akrual dalam Akuntansi Pemerintahan di Indonesia. Bahan Bahasan untuk Limited Hearing. Jakarta

Margono, Akuntansi Berbasis Akrual bagi Satuan Kerja Perangkat Daerah, Warta Finance (http://www.wartafinance.com/wiki/keuangan-berbasisakrual, di akses tanggal 11 Agustus 2015)

Pemerintah Republik Indonesia, Peraturan Pemerintah Nomor 71 Tahun 2010 tentang Standar Akuntansi Pemerintahan

Satish. 2004. Model View Controller (MVC) Architecture, (Online), (http:// www.dotnetspider.com/resources/316-
Model-View-Controller-MVC- architecture.aspx, diakses tanggal 10 Maret 2014).

Simanjuntak, Binsar $\mathrm{H}$ Penerapan Akuntansi Berbasis Akrual di Sektor Pemerintahan di Indonesia. Jakarta: Kongres XI IAI

Software Engineering Standards Committee of the IEEE Computer Society, 1998, IEEE 830-1998 Recommended Practice for Software Requirements Specifications, The Institute of Electrical and Electronics Engineers, Inc.

Whitten, Jeffery, L., etc, 2004, Systems Analysis and Design Methods, The McGraw-Hill Companies,Inc

Widjajarso, Bambang. 2010. Penerapan Basis Akrual pada Akuntansi Pemerintahan Indonesia: Sebuah Kajian Pendahuluan. Disampaikan dalam seminar "Strategi Menuju Penerapan Akuntansi Akrual pada Instansi Pemerintahan" Pusat Pendidikan dan Pelatihan Anggaran \&PerbendaharaanBadan Pendidikan dan Pelatihan Keuangan. Yogyakarta

Yafie, M, D. 2013. Penerapan Basis Akrual pada Standar Akuntansi Pemerintahan Indonesia. Ejournal.unesa.ac.id. volume 2 nomer 1 